\title{
EESTI 1930. AASTATE AJALOO KIRJUTAMISEST PAGULUSES
}

\author{
Peeter Kenkmann
}

1930. aastad olid Eestis sündmusterohked. Kümnendi alguses jõudis siia ülemaailmne majanduskriis ja tõi kaasa poliitilise kriisi, sh täitevvõimu ebastabiilsuse suurenemise. Lahendusena nägid paljud täitevvõimu tugevdamist ja suure võimuga riigipea institutsiooni loomist. Valitsemissüsteemi reformi nõudis ka samal ajal poliitikasse tulnud vabadussõjalaste liikumine, mille põhiseaduse muutmise ettepanek kiideti ülekaalukalt heaks 1933. aasta oktoobris toimunud rahvahääletusel. Nn 1933. aasta põhiseadus ei hakanud kunagi täies ulatuses kehtima, sest riigivanem Konstantin Päts teostas kindral Johan Laidoneri ja jõustruktuuride toel 12. märtsil 1934 riigipöörde, lükkas edasi aprillis 1934 toimuma pidanud valimised ning, peatades enamiku põhiseaduses loetletud nn. kodanike põhiõiguste kehtimise, hakkas valitsema autoritaarselt. 1936. aastal toimus järjekordne rahvahääletus, millega Päts nõutas endale mandaadi rahvuskogu kokkukutsumiseks ja veelkordseks põhiseaduse muutmiseks. Uus põhiseadus hakkas kehtima 1. jaanuaril 1938, aprillis kogunes selle alusel valitud-nimetatud kahekojaline parlament ja Päts valiti valimiskogu poolt Eesti esimeseks presidendiks. Kodanike põhiõiguste teostamine jäi aga endist viisi piiratuks kuni Eesti okupeerimise ja annekteerimiseni Nõukogude Liidu poolt suvel 1940.

Käesoleva artikli eesmärgiks on analüüsida, kuidas kujutati Eesti vabariigi 1930. aastate sisepoliitikat paguluses ja milline poleemika sellega kaasnes ning konstrueerida üks valdava enamuse käsitluste seisukohti arvestav kirjeldus nimetatud perioodist ja võrrelda seda teema praeguse uurimisseisuga.

Eestlaste teadustegevus paguluses oli aktiivne. Eesti teaduse traditsioonide jätkamiseks asutasid põgenikud välismaal teadusseltse, nagu Eesti Teaduslik Selts Rootsis ja Eesti Teaduslik Ühing Ameerikas, samuti jätkus paguluses üliõpilasorganisatsioonide tegevus. On märkimisväärne, et kui üliõpilasorganisatsioonide väljaannetes paguluses avaldati mitmeid käesoleva artikli uurimisteema kohaseid käsitlusi, siis vähemalt Eesti 
Teadusliku Seltsi Rootsis väljaannetes need puudusid. ${ }^{1}$ Paguluses toimunud teadustegevust, sh ajalookirjutust on mõnevõrra uuritud ${ }^{2}$, kuid puudub uurimus spetsiifiliselt 1930. aastate sündmuste kohta. Üks erand on Rein Taagepera artikkel ${ }^{3}$, kus autor analüüsis peamiselt võõrkeelset kirjandust Balti riikide ajaloo kohta.

Eesti 1930. aastate sisepoliitika kohta paguluses kirjutatut on vähesel määral käsitlenud hilisemad uurijad. Rein Marandi kirjutas oma peateose "Must-valge lipu all" I köite eessõnas, et selgelt eristuvad nn võitjate ja kaotajate ajalood. Võitjate poolelt nimetas ta Eduard Laamani teost "Konstantin Päts: poliitika- ja riigimees" (1940) ja Märt Raua raamatut "Kaks suurt: Jaan Tõnisson, Konstantin Päts ja nende ajastu" (1953) ning osaliselt ka Artur Mägi uurimust "Das Staatsleben Estlands während seiner Selbständigkeit" (1967). Kaotajate ajalugu oli aga William Tominga "Vaikiv ajastu Eestis" (1961). Kõigis neis esines Marandi sõnul ebatäpsusi või vigu. Otseselt kummassegi gruppi liigitamata ja seal muid vigu leidmata, peale teemakohastele arhiiviallikatele juurdepääsu puudumise, mainis Marandi Imre Lippingu käsitlust "Emergence of Estonian authoritarianism" (1974) ja Tõnu Parmingu "The collapse of liberal democracy and the rise of authoritarianism in Estonia” (1975). ${ }^{4}$

Taasiseseisvunud Eestis ilmunud üldkäsitluses "Eesti ajalugu VI" nentis Ago Pajur, et Teise maailmasõja järel sai Eesti ajalugu objektiivselt uurida vaid väljaspool Nõukogude Liitu. Objektiivsete käsitluste hulka kuuluvatena nimetas ta Harri Moora ning August ja Leida Annisti (varjunimede M. Ojamaa ning A. ja T. Varmas all) 1946. aastal ilmunud "Eesti ajalugu” ning Evald Uustalu, Evald Blumfeldti, Georg von Rauchi, A. Mägi ja R. Marandi käsitlusi. Ebaobjektiivsete hulka kuulusid Pajuri meelest aga W. Tominga ja M. Raua teosed. ${ }^{5}$ Magnus Ilmjärv uuris Eesti ja teiste Balti

\footnotetext{
1 Alates 1952. aastast ilmus regulaarselt seltsi aastaraamat, kus avaldati eesti teadlaste uurimusi, ülevaateid seltsi ettekandekoosolekute kohta ja uurimistööde konkurssidel auhinnalisi kohti saavutanud tööde nimekirju. Kuigi Eesti ajalugu tervikuna oli populaarne, puudusid kuni 1988. aastani nii aastaraamatus avaldatud tööde kui ettekandekoosolekutel tehtud ettekannete ja uurimistööde konkurssidele esitatud uurimuste hulgas 1930. aastate Eesti sisepoliitikale pühendatud tööd.

2 Vt nt artikleid ajalookirjutuse kohta paguluses järgmises kogumikus: East and Central European history writing in exile 1939-1989, ed. by Maria Zadencka, Andrejs Plakans, Andreas Lawaty (Brill Rodopi: Leiden and Boston, 2015).

3 Rein Taagepera, "Heitlus Balti ajaloo pärast", Akadeemia, 12 (2008), 2605-2623.

4 Rein Marandi, Must-valge lipu all: vabadussõjalaste liikumine Eestis 1929-1937, I: legaalne periood (1929-1934) (Stockholm: Department of Baltic Studies at the Stockholm University, 1991), 2-4.

5 Eesti ajalugu, VI: Vabadussõjast taasiseseisvumiseni, peatoim Sulev Vahtre (Tartu: Ilmamaa, 2005), 13-14, 138.
} 
riikide välispoliitikat kuni Nõukogude okupatsioonini. Tema hinnangul kirjutasid teaduslikul tasemel töid paguluses üksikud eestlased, nimetades E. Uustalu ja T. Parmingut. Samuti väitis Ilmjärv, et paguluses kehtis nn poliitilise korrektsuse doktriin, mille järgijad ei kiitnud heaks autoritaarrežiimi kritiseerimist. ${ }^{6}$

Ka paremradikaalidest sõdadevahelises Eestis raamatu kirjutanud Andres Kasekamp oli kriitiline paguluses avaldatu osas. Tema sõnul põhines vabadussõjalaste retseptsioon paguluses (M. Raud, E. Uustalu, A. Mägi) peamiselt E. Laamani poolt loodud kuvandil, mille lihtsustatud ja tendentsliku käsitluse võtsid veidi tasakaalukamalt üle ka lääne teadlased (G. von Rauch ja Toivo U. Raun). Sellele vaidlesid vastu üksikud autorid (W. Tomingas). Käesolevas artiklis analüüsitavate teoste seast nimetas Kasekamp tõsiseks uurimuseks vaid T. Parmingu teost. ${ }^{7}$

2009. aastal avaldas Pajur artikli vabadussõjalaste retseptsioonist, kus kirjeldas H. Moora ning A. ja L. Annisti, M. Raua, J. Remmelga ja W. Tominga käsitlusi ning mainis ka I. Lippingu, T. Parmingu ja R. Marandi teoseid. Pajur tõstis esile viimaseid kolme kui professionaalseid uurijaid, samas küsides, kui palju suutsid nende teaduslikud käsitlused murda eelnevate poolt kinnistatud vaateid. ${ }^{8} 2018$. aastal K. Pätsist poliitilise biograafia avaldanud Pajuri hinnangul viljeldi paguluses "vaikiva oleku vaimule" sarnast suunda, kujutades (sh E. Laaman ja M. Raud) Pätsi selgelt positiivselt, et mitte öelda ülistavalt. ${ }^{9}$

Tegelikult oli paguluses Eesti 1930. aastate sisepoliitika kohta avaldatud teoste arv suurem, kui eelnevalt loetletud käsitlused. Need ei ole aga oma mahult, allikabaasilt, teaduslikult tasemelt ega leviku ja mõju ulatuselt võrdsed, nagu ei olnud sarnased ka autorite teaduslik ettevalmistus ega teoste kirjutamise eesmärk. Tuleb arvestada, et nii teoste endi kui nende kohta Välis-Eesti ajakirjanduses avaldatud ja tihti väga emotsionaalsete arvustuste autoritel olid oma tegevuseks erinevad, sh poliitilised sihid.

Kuna käesoleva artikli peaeesmärgiks on uurida, kuidas paguluses 1930. aastate Eesti sisepoliitilisi võtmesündmusi kujutati, siis on teaduslike käsitluste kõrval olulised ka nn propagandateosed, mis aitavad uuritavast

\footnotetext{
6 Magnus Ilmjärv, Hääletu alistumine: Eesti, Läti ja Leedu välispoliitilise orientatsiooni kujunemine ja iseseisvuse kaotus 1920. aastate keskpaigast anneksioonini (Tallinn: Argo, 2004), 15.

7 Andres Kasekamp, The radical right in interwar Estonia (Basingstoke, London: Macmillan Press, 2000), 2.

8 Ago Pajur, "Vabadussõjalaste retseptsioon Pätsi ajast kaasajani", Tuna, 3 (2009), 37-39.

9 Ago Pajur, Konstantin Päts: poliitiline biograafia, II: riigimees (1917-1956) (Tartu: Rahvusarhiiv, 2018), 9.
} 
perioodist tuvastada episoode, mida üritati “ümber kirjutada” või hoopis maha vaikida.

Laiale lugejaskonnale mõeldud, ja seetõttu väliseesti ajakirjanduses ohtralt reklaamitud, eestikeelsete populaarteaduslike ja tihti tendentslike järeldustega üldkäsitluste mõju oli pagulastele kahtlemata palju suurem kui professionaalsete uurijate võõrkeelsetes teadusajakirjades avaldatud teadusartiklitel, millest lai lugejaskond tihti kuulnudki polnud. Teoseid arvustasid tihti mitte professionaalsed ajaloolased, vaid ajakirjanikud, endised poliitikud jt, samuti olid nii käsitluste lugejad kui nende põhjal pagulasmeedias tekkinud arutelu jälgijad väga erineva elukäigu, haridusliku tagapõhja, teadmiste ja poliitiliste eelistustega. Valdaval osal autoritest, arvustajatest ja lugejatest olid ju 1930. aastate Eestist isiklikud mälestused, mitmed aga olid sündmustes ametikoha või poliitilise tegevuse tõttu ise osalenud, soovides seega näidata oma varasemat tegevust soodsas valguses.

Käesolevas artiklis kavatsen ma uurida paguluses avaldatud teostes esitatud seisukohti viie küsimuse kohta: kuidas kirjeldati olukorda Eestis 1930. aastate alguses, milline oli hinnang vabadussõjalaste liikumisele, 12. märtsil 1934 toimunule, kuidas kirjeldati aastaid 1934-37 ning kas autorite hinnangul võeti aastatel 1938-40 Eestis suund demokraatia taastamise poole.

Teosed, millest ma neile küsimustele vastuseid otsin, olid kirjutatudkoostatud eesti päritolu autorite poolt ja antud välja paguluses enne Eesti iseseisvuse taastamist nii eesti kui võõrkeeltes. Oma suure leviku ja historiograafilise tsiteeritavuse pärast on erandiks E. Laamani raamat K. Pätsist, millest paguluses ilmus mitte esma-, vaid täiendatud kordustrükk (lisandus 1938.-40. aasta käsitlus ajakirjanik Voldemar Kureselt), ja R. Marandi uurimuse "Must-valge lipu all" 1997. aastal ilmunud II köide, mis moodustab 1991. aastal ilmunud I köitega ühe terviku. Üksikisikute mälestusi ma ei analüüsi. Valiku hulgas on peale akadeemiliste uurimuste ka ilma viiteaparatuurita Eesti ajaloo üldkäsitlusi, artiklite kogumikke, üliõpilasseltside ja korporatsioonide koguteoseid, juhtivate poliitikute juubelite tähistamiseks koostatud nn mälestusraamatuid jne. Kindlasti ei õnnestunud leida kõiki paguluses Eesti 1930. aastate sisepoliitika kohta avaldatud teoseid, kuid valik peaks olema piisavalt representatiivne. Artikli piiratud maht ei võimalda detailselt käsitleda analüüsitavate teoste ilmumise järel nende kohta ajakirjanduses avaldatud arvamusi, seda teemat puudutan ma esimeses peatükis vaid riivamisi. 


\section{Eesti vabariigi 1930. aastate sisepoliitika kajastamist paguluses mõjutanud tegurid}

Kuigi ajalookirjutust ei mõjutanud enam 1930. aastate teisel poolel Eestis kehtinud tsensuur, rõhutati paguluses aktiivselt tegutsenud poliitikute sõnavõttudes ja pagulasmeedias, sh raamatute arvustustes tihti, et Eesti iseseisvuse taastamise eest peetava võitluse huvid on kõige tähtsamad ja neid tuleks arvestada ka Eesti ajaloo kirjutamisel.

Näiteks kirjutas III-V riigikogu ja Eesti eksiilvalitsuse liige Johannes Sikkar, et 1930. aastate Eesti sisepoliitilised sündmused muudavad pagulastele keerulisemaks võidelda Nõukogude Liidu propagandaga ning selgitada maailma avalikkusele, et Eesti oli demokraatlik riik. Sikkari arvates pidi Eesti orienteeruma demokraatlikele lääneriikidele ja seega näitama, et 1930. aastate liialdused, nii vabadussõjalased kui "vaikiv ajastu", olid vaid rahva demokraatliku enamuse survel mööduvad nähtused..$^{10}$ Ajakirjanik ja endine propagandatalituse töötaja Voldemar Kures avaldas paguluses korduvalt pahameelt 1930. aastate Eesti sisepoliitika ebasobiva kujutamise pärast, eriti kui vastav tekst sattus võõrkeelsetesse teostesse. ${ }^{11} 1930$. aastate teise poole Eesti eliiti ja ühiskonnakorda kritiseerivaate seisukohtade jõudmise üle võõrkeelsetesse teostesse tundsid muret teisedki. ${ }^{12}$

1953. aastal pöördus teadustöö kõrval ka ajakirjanikuna töötanud Rein Marandi 1934. aasta sündmuste 20. aastapäevaga seoses August Rei poole, et viimane kirjeldaks sotsialistide ja Pätsi vahel 1933. aasta lõpul sõlmitud kokkulepet, mis sillutas tee 12. märtsi riigipöördele. Rei keeldus vastamisest, väites, et tema arvates pole "selle küsimuse ülestõstmine praegusel ajal ei vajalik ega ka otstarbekohane ja soovitav". ${ }^{13}$ Poliitikute kõrval ka ajaloolaste seas valitsevale enesetsensuurile viitab E. Uustalu ja W. Tominga kirjavahetus 1975. aastast. Viimase küsimusele - "Ütelge mulle, kas Teie kui ajaloolase autoriteetse arvamise järele vaikival ajastul Eestis oli diktatuur?" - olevat Uustalu vastanud: "Oli küll. Aga head kombed ei luba sellest kõneleda." ${ }^{14}$

\footnotetext{
10 Johannes Sikkar, "Pagulaskonna ideoloogiline hoiak", Hoiak: koguteos, toim Artur Grönberg, Aleksander Kaelas, Aksel Mark (Stockholm: Eesti Teataja, 1946), 8-9.

11 Fakt, “"Sisepoliitika” varjutab välisprobleemid”, Stockholms-Tidningen Eestlastele, 19. oktoober 1949, 1; Fakt, "Kus on kuninga Eesti külaskäigu film?”, Stockholms-Tidningen Eestlastele, 3. november 1950, 1; Fakt, “Tühjajutu entsüklopeediad”, Stockholms-Tidningen Eestlastele, 13. september 1952, 1.

12 “Mamersi mälestusraamat vaatluse ja kriitika all”, Teataja, 29. aprill 1959, 6.

13 Riksarkivet [Rootsi Riigiarhiiv, edaspidi SRA], Baltiska Arkivet, Rei's arkiv, kartong 5.

14 Tomingase kiri T. Kintile 19. märtsil 1975: SRA, Baltiska Arkivet, Kint's arkiv, kartong 27 , mapp 2.
} 
Ka Eesti Üliõpilaste Seltsi 1985. aastal avaldatud ajaloos soovitatakse "vaikivat ajastut" ülemäära mitte kritiseerida, kuna see "ei teeniks asjalikku eesmärki ning seega oleks sobimatu". EÜS-i "tagasihoidlikkust" võib selgitada asjaoluga, et organisatsioon oli otseselt seotud Pätsi riigipöördega, näiteks olid seltsi liikmed kaitseliidu akadeemilisest malevkonnast nende väheste seas, keda 12. märtsi ööl usaldati relvastatult patrullima. ${ }^{15}$

Negatiivselt arvustati enamikku käesolevas artiklis mainitud teoseid, kus Pätsi ja nn autoritaarkorda mingiski ulatuses kritiseeriti. Kõige jõulisemalt Pätsi rünnanud J. Remmelgat ja W. Tomingat süüdistati otse vabadusvõitluse kahjustamises ja sovetipropagandale materjali andmises ${ }^{16}$, vähemkriitilisi autoreid, nagu näiteks H. Moora ning A. ja L. Annist, A. Mägi, teose "Eesti ajalugu noorsoole" autorid, R. Marandi või Helmut Maandi, noomiti leebemalt üksikute "liialduste" pärast. ${ }^{17}$

Sellele tendentsile oli ka vastuvaidlejaid, kes jäid aga vähemalt ajakirjanduses vähemusse. 1953. aastal avaldas ajaloolane Aleksander Loit ajakirjas Vaba Eesti artikli, milles kritiseeris väikese (täpsemalt tutvustamata) grupi pagulaste poolt propageeritavat seisukohta, et teatud perioodid ja isikud Eesti ajaloos (vihjates K. Pätsile ja "vabariigi lõpuaastatele") peaksid jääma uurimise-arvustamise alt välja. Autori enda arvates võis taoline tegevus iseseisvuse taastamise eest peetavale võitlusele, kui see toimub rahvusvahelisele õigusele apelleerides, hoopis kahju tuua. ${ }^{18}$

1955. aastal kritiseeris paguluses vabadussõjalastest loodud pilti ajakirjanik Oskar Mänd, märkides muuhulgas: "Nagu näeme, on rida autoreid

15 Ilmar Rebane, "Põhiseaduse kriisist baasideni 1932-1939", Eesti Üliópilaste Selts 1870-1970, koost Arno Raag jt (Toronto: Eesti Üliõpilaste Seltsi Vanematekogu Kirjastus, 1971), 95-104, 111; Artur Grönberg, Eesti Üliõpilaste Seltsi ajalugu, 2: iseseisvuse eelvõitluses (1906-1917), omariikluse saavutustes (1918-1940) (Montreal: Eesti Üliõpilaste Seltsi Vanematekogu Kirjastus, 1985), 369, 408.

16 "Piinlik kallaletung Eesti riigile ja selle juhtidele", Välis-Eesti, 3. september 1960, 1; “Tõe tohterdajad", Vaba Eesti Sõna, 8. veebruar 1962, 5; Leonhard Vahter, "Üks pahatahtlik faktide pea peale pööramine”, Vaba Eesti Sõna, 8. veebruar 1962, 11; Leonhard Vahter, "Üks pahatahtlik faktide pea peale pööramine, II", Vaba Eesti Sõna, 15. veebruar 1962, 11. Siin on ära toodud üksnes väike loetelu Tominga raamatu kohta pagulasmeedias avaldatud arvamustest. Ainuüksi selle raamatu ümber puhkenud poleemika vääriks omaette artiklit.

17 Kp, “Oli see tõesti nii?", Välis-Eesti, 29. detsember 1946, 4; Tõnis Kint, "Valimispropaganda hüdropuldiga", Välis-Eesti, 9. september 1951, 4; Artur Adson, "Eesti ajalugu noorsoole", Vaba Eestlane, 28. mai 1955, 4; Ar-Gi, "Mahukas-sisukas album", Teataja, 26. veebruar 1987, 1; Johannes Kaup, "Teretulnud lisa meie ajaloole", Tulimuld, 3 (1988), 164-165; vt ka Helmut Maandi, "Sündmusterikas aasta, II", Akadeemia, 2 (2008), 383.

18 Aleksander Loit, "Vabariik tabu?", Vaba Eesti tähistel: valimik tsensuurivaba eesti mõttelugu aastaist 1948-64, koost Hellar Grabbi, Ivo Iliste, Vahur Linnuste (Tallinn: Eesti Entsüklopeediakirjastus, 2000), 30-32. 
omal ajal vapside suhtes vastaste poolt esitatud kahtlustusi nüüd serveerinud kui vaidlematuid tõsiasju." Kirjaga koos avaldati lehe toimetuse kommentaar, mille kohaselt: "End. "Postimehe" peatoimetaja ja "Päevalehe" tegevtoimetaja $\mathrm{O}$. Männa avalik sõnavõtt on kõigiti põhjendatud, sest vabadussõjalaste liikumise ajaloolist osa on saanud siiani valgustada ainult "üks pool”, s.o. vastased sisepoliitilistel motiividel." ${ }^{19} \mathrm{Ka}$ R. Marandi kritiseeris korduvalt arvamust, et Eesti 1930. aastate sisepoliitilist ajalugu tuleb ilustada vabadusvõitluse huvides. ${ }^{20}$

Nn võitjate ajalugu (E. Laaman ja M. Raud) kritiseeriti harva ja suhteliselt leebelt. ${ }^{21}$

Paljud Eesti tuntuimad riigitegelased ja poliitikud olid jäänud sovetirežiimi küüsi ning tapetute või teadmata saatusega küüditatutena muutunud Eesti iseseisvuse märtriteks, kelle varasemat tegevust ei sobinud kritiseerida. ${ }^{22}$ Pagulasmeedias ei tehtud K. Pätsil ja J. Laidoneril vahet Jaan Tõnissoniga - kõiki kolme kujutati Eesti tähtsaimate riigimeestena ja nende suuri teeneid toodi peaaegu võrdselt esile kõigil kümnenditel. ${ }^{23}$ Tõnissoni tunnustamine ei laienenud aga nn Tartu opositsioonile tervikuna, mida korduvalt süüdistati lisaks poliitilisele intriigitsemisele ja Pätsile vastutöötamisele ka koostöös kommunistidega. ${ }^{24}$

1930. aastate ajaloo uurimist paguluses takistas lisaks lühikesele ajalisele distantsile ja teema poliitilisele tundlikkusele ka asjaolu, et enamik teemakohaseid kirjalikke allikaid, sh riigiasutuste arhiivid, oli jäänud Eestisse. Seega kirjutati peamiselt mälestuste, Eesti riigiasutuste publitseeritud materjalide, alates 1934. aasta märtsist tsenseeritud olnud ajakirjanduse ja väheste varem avaldatud uurimuste põhjal, mis, sarnaselt ajakirjandusega, ei olnud "vaikiva ajastu" tõttu kuigi objektiivsed. Neile olulistele puudustele juhiti teostes tähelepanu valikuliselt ja erineva detailsusega, kuid teaduslikud käsitlused olid selles kindlasti põhjalikumad. Käesoleva artikli piiratud maht ei võimalda uurida, milliste allikate põhjal iga konkreetne

19 Oskar Mänd, “Üks Kiri”, Võitleja, 1. mai 1955, 5.

20 Rein Marandi, “Teretulnud teos”, Teataja, 20. detsember 1975, 6; Rein Marandi, "Demokraatia", Teataja, 25. aprill 1987, 4.

21 Aksel Mark, "Veelkord "Konstantin Päts”“', Teataja, 1. aprill 1978, 7; Voldemar Kures, Seitsme lukuga suletud raamat, III (Tartu: Ilmamaa, 2007), 43.

22 Vt nt "Vaidlusõhtu Eesti iseseisvuse kaotamise ümber", Eesti Päevaleht, 28. oktoober $1981,1$.

23 Mõned näited 1948., 1958., 1971. kui 1988. aastast: Põgenik, “Aeg nõuab kainust", Eesti Post, 27. aprill 1948, 2; "Tulevased Eesti noortejuhid õppelaagris", Vaba Eesti Sõna, 12. juuni 1958, 9; Eesti Päevaleht, 24. veebruar 1971, 2; "Eesti iseseisvuse suurkujud", Võitleja, 1. jaanuar 1988, 4, 6.

24 Vt. nt. "Baltimaade režiimid ajaloovalguses", Võitleja, 1. september 1965, 1. 
autor oma teose kirjutas ja kui kriitiliselt autorid kasutatud allikatesse suhtusid. See ei ole ka artikli eesmärgiks.

Nn pagulasajaloo peavoolule esitasid väljakutse noorema põlvkonna teadlased - T. Parming, R. Marandi, R. Taagepera ja I. Lipping -, kes soovisid teha teadust väljaspool poliitikute seatud piiranguid. Kuigi nimetatud teadlaste järgnevalt kirjeldatud seisukohtadel ei olnud enamasti otsest sidet nende 1930. aastate Eestit puudutavate teadustöödega, näitab see ometi, kui politiseeritud kogu kodumaaga seotu paguluses oli ja kuidas nn poliitiliselt ebakorrektsete arvamuste avaldajatega käituti.

Aastatel 1957-58 nahutas pagulasajakirjandus R. Marandit, kes olevat saatnud vahendajate kaudu kirja Eesti NSV-sse Jaan Krossile. Marandi sildistati "punaseks", teda süüdistati kodumaa olude mittetundmises, nooruses ja kogenematuses ning seati kahtluse alla tema pädevus teadlasena. ${ }^{25}$ Samuti kritiseeriti Marandi seisukohti 1967. aastal, kui ta rääkis nn Paasikivi liini rakendamisest Eesti ja Nõukogude Liidu suhetes, viimasega usalduslike suhete loomisest ja kodumaa külastamisest. ${ }^{26}$

R. Taagepera polemiseeris 1963. aastal Vaba Eesti Sõna toimetusega, avaldades toetust ühe teise autori (Reino Sepa) pagulasajakirjandust ebaobjektiivsuse pärast kritiseerivale artiklile. Ajalehe toimetus vastas omakorda kommentaariga, milles kritiseeris Taagepera "liberaalitsemise" ja 1940.-41. aasta kannatuste mittetundmise pärast. ${ }^{27}$

1970. aastate alguses seati kahtluse alla T. Parmingu pädevus teadlasena, kuna ta oli oma loengutes väitnud, et vaatamata formaalsele neutraalsusele oli Eesti 1930. aastate lõpus orienteeritud Saksamaale ja see võis mõjutada Nõukogude Liitu Eestit annekteerima. ${ }^{28}$

Vaba Eesti Sõna näitas noore ja asjatundmatuna ka I. Lippingut, kirjeldades tema vaidlust eesti pedagoogi Salme Pruudeniga. Lipping kritiseeris Pruudenit Pätsi diktatuuri idealiseerimise pärast, viimane aga väitis, et Lipping ei tunne tausta: “Teie näete diktatuuri Eestis kõige halvemal kujul. [...]

25 I.V., "Eestlased Rootsis koeksisteerimas", Vaba Eestlane, 11. detsember 1957, 6; H. Raudsepp, "Kremlikoolid ja krossid", Vaba Eesti Sõna, 12. detsember 1957, 2; N., "Eesti dumpingu-katsed pagulaste kirjandusturul", Vaba Eesti Sõna, 9. jaanuar 1958, 5. 26 “"Paasikivi liin" ja "Marandi liin"“, Teataja, 28. veebruar 1969, 2.

27 “Informatsioon okupeeritud kodumast", Vaba Eesti Sõna, 29. august 1963, 10.

28 Leonhard Vahter, "Noor teadlane süüdistab iseseisvuse juhtkonda Eesti vabadusekaotuses", Eesti Päevaleht, 25. juuli 1973, 4-5; "Kas Eesti oli Saksa orientatsiooniga", Vaba Eesti Sõna, 10. mai 1973, 2; "Kas Eesti iseseisvuse kaotamine oli paratamatu", Vaba Eesti Sõna, 18. aprill 1974, 5; "Kas Eesti iseseisvuse kaotamine oli vältimatu", Vaba Eesti Sõna, 8. august 1974, 5. Nendes artiklites läks Vahter mööda "vaikivast ajastust". Parming vastas Vahterile 21. novembri 1974 Vaba Eesti Sõnas, kuid üksnes Eesti välispoliitikaga seotud teemadel. 
Meie diktatuur oli parem kui praegune kriisi põdev lääne demokraatia oma korralageduse ja vabaduse kurjasti tarvitamisega, mida ka ainult diktatuur võib lõpetada. Kahjuks jäi aeg lühikeseks uue põhiseaduse rakendamisel." ${ }^{29}$

\section{Teostes esitatud seisukohad}

Olukord Eestis 1930. AASTATE ALGUL. 1930. aastate alguse poliitilise olukorra kirjeldamisel juhtis enamus autoritest tähelepanu 1920. aasta põhiseaduse puudustele: parlamendi domineerimisele ja riigipea institutsiooni puudumisele. Seda märkisid H. Moora ning A. ja L. Annist, W. Tomingas, A. Mägi, E. Uustalu, A. Rei, T. Parming, G. von Rauch, Romuald J. Misiunas ja R. Taagepera, T. Raun jt. ${ }^{30}$

Lisaks rõhutasid E. Laaman ja M. Raud K. Pätsi erilist rolli 1920. aasta põhiseaduse muutmise katsetes, kirjeldades teda kui nn mõistuse häält ja erakondadeülest poliitikut. Jaan Tõnissoni kirjeldas Raud kui väsimatut Põllumeeste Kogude poliitika vastu võitlejat ning erakondi tervikuna intriigitsejate ja põhimõttelagedatena. ${ }^{31}$ Pätsi rolli rõhutati juba H. Moora

29 Salme Pruuden, "Noored ja Eesti Vabariik", Vaba Eesti Sõna, 6. juuli 1978, 5, 7.

30 M. Ojamaa, A. Varmas, T. Varmas, Eesti ajalugu (Stockholm: Eesti Teaduslik Selts Rootsis, 1946), 358; Johannes Klesment, "Jooni Jüri Uluotsa poliitilisest ideoloogiast”, Prof. Jüri Uluotsa mälestusraamat, toim Johannes Klesment, Hanno Kompus, Edgar Valter Saks (Stockholm, 1945), 16-17; Otto Pukk, "Jüri Uluots riigimehena", Prof. Jüri Uluotsa mälestusraamat, toim Johannes Klesment, Hanno Kompus, Edgar Valter Saks (Stockholm, 1945), 22-23; Evald Blumfeldt, "Eesti riigi rajamine ja areng", Eesti riik ja rahvas Teises maailmasõjas, 1: Eesti nagu ta oli, toim Richard Maasing jt (Stockholm: EMP, 1954), 31-33; William Tomingas, Vaikiv ajastu Eestis (Tallinn: Grenader, 2013 [esmatrükk Stockholm, 1961]), 22-35; Artur Mägi, Kuidas valitseti Eestis (Stockholm: Tõrvik, 1951), 40-57, 82-86; Evald Uustalu, The history of Estonian people (London: Boreas, 1952), 203; Jüri Parijõgi, Toomas Algma, Jakob Koit, Eesti ajalugu noorsoole (Stockholm: Vaba Eesti, 1954), 296-297; Eesti põllumeeste poliitika: ülevaade Eesti põllumeeste liikumisest 1917-1955, koost Osvald Viirsoo (Lund: Eesti Põllumeeste Kogude Esindus Paguluses, 1956), 88-89; Eesti Vabariik 1918-1940: ajalooline ülevaade sõnas ja pildis, koost Evald Uustalu (Lund: Eesti Kirjanike Kooperatiiv, 1968), 67-68, 79-81; August Rei, The drama of the Baltic peoples (Stockholm: Vaba Eesti, 1970), 163-165; Georg von Rauch, The Baltic States: the years of independence: Estonia, Latvia and Lithuania 1917-1940 (London: Hurst, 1974), 146-148; Tõnu Parming, The collapse of liberal democracy and the rise of authoritarianism in Estonia (London, Beverly Hills: SAGE, 1975), 8, 38-41; Romuald J. Misiunas, Rein Taagepera, The Baltic States: years of dependence 1940-1980 (London: Hurst, 1983), 11-12; Helmut Maandi, "Rahvaesindustest iseseisvas Eestis", Eestit tagasivaates, toim Esmo Ridala (Stockholm: EÜS Põhjala, 1987), 21-22; Toivo U. Raun, Estonia and the Estonians (Stanford: Hoover Institution Press, 1987), 112-115.

31 Eduard Laaman, Konstantin Päts, poliitika- ja riigimees (Stockholm: Vaba Eesti, 1949), 219-235; Märt Raud, Kaks suurt: Jaan Tõnisson, Konstantin Päts ja nende ajastu (Tallinn: Olion, 1991), 178-186; Märt Raud, Riigiehitaja Konstantin Päts (Stockholm: Eesti Põllumeeste Kogude Esindus Paguluses, 1977), 111-115. 
ning A. ja L. Annisti raamatus, kuid mitte ühemõtteliselt positiivsena autorite sõnul nõudsid Põllumeeste Kogud põhiseaduse muutmist lootuses saada presidendi koht enda kätte. ${ }^{32}$

Neli autorit juhtisid tähelepanu aastatel 1932-33 rahvahääletusele esitatud põhiseaduse muutmise eelnõude suurele omavahelisele sarnasusele, vaieldes seega vastu seisukohale vabadussõjalaste eelnõu erilisest autoritaarsusest. W. Tomingas ja H.-J. Uibopuu leidsid, et vabadussõjalaste eelnõu ja teise Riigikogu eelnõu vahel olulisi erinevusi ei olnud. ${ }^{33}$ Sama märkisid kõigi kolme eelnõu kohta ka R. Marandi ja T. Raun. ${ }^{34}$

Kolmes teoses 1920. aasta põhiseadust ei kritiseeritud: R. Marandi hinnangul oli põhiseaduse muutmine pseudoprobleem ning 1930. aastate alguse valitsuskriisides olid süüdi majanduskriisi mõjud. Samuti oli põhiseaduse muutmise soov kahjulik, kuna andis positiivse eesmärgi vabadussõjalastele. ${ }^{35} \mathrm{E}$. Uustalu nentis, et 1920. aasta põhiseaduse alusel loodud riigikord ei olnud nii nõrk, kui võis järeldada üksnes valitsuskriiside arvu järgi ${ }^{36}$, ning I. Lipping väitis, et 1920. aasta põhiseaduse puudused olid liialdatud ja 1930. aastate alguseni oli suudetud selle alusel riiki juhtida. ${ }^{37}$

Hinnang vabadussõjalastele. Suur hulk autoreid (H. Moora ning A. ja L. Annist, J. Sikkar, Rudolf Penno, Eesti ajalugu noorsoole, E. Uustalu, A. Rei, G. von Rauch, R. Taagepera, T. Parming, H. Maandi ja T. Raun) väitsid, et vabadussõjalased võtsid eeskuju Saksamaa, Itaalia või Soome äärmusliikumistest. ${ }^{38}$ Johannes Klesment ja Evald Blumfeldt nimetasid

\footnotetext{
32 Ojamaa, Varmas, Varmas, Eesti ajalugu, 358.

33 Tomingas, Vaikiv ajastu Eestis, 432; Henn-Jüri Uibopuu, "The constitutional development of the Estonian Republic", Journal of Baltic Studies, 1 (1973), 17.

34 Rein Marandi, "Riigivõimude tasakaalu otsingul. Põhiseaduse parandamise püüdlused Eestis 1929-1933”, Eestit tagasivaates, toim Esmo Ridala (Stockholm: EÜS Põhjala, 1987), 63; Raun, Estonia and the Estonians, 117.

35 Marandi, "Riigivõimude tasakaalu otsingul", 65.

36 Eesti Vabariik 1918-1940, 80-81.

37 Imre Lipping, "Emergence of Estonian authoritarianism", Baltic History, ed. by Arvids Ziedonis Jr., William L. Winter, Mardi Valgemäe (Columbus: Association for the Advancement of Baltic Studies, 1974), 209-211.

38 Ojamaa, Varmas, Varmas, Eesti ajalugu, 359; Sikkar, "Pagulaskonna ideoloogiline hoiak", 8-9; Rudof Penno, "Erakonnad Eestis", Hoiak: koguteos, toim Artur Grönberg, Aleksander Kaelas, Aksel Mark (Stockholm: Eesti Teataja, 1946), 33; Rudolf Penno, "Eesti vabadusvõitluse traditsioon ja Eesti Rahvusnõukogu", Eesti Rahvusnõukogu toimetised, 1 (1948), 13; Parijõgi, Algma, Koit, Eesti ajalugu noorsoole, 297; Eesti Vabariik 1918-1940, 137-138; Uustalu, The history of Estonian people, 204; Rei, The drama of the Baltic peoples, 164; Rauch, The Baltic States, 149; Rein Taagepera, "Civic culture and authoritarianism in the Baltic States, 1930-1940", East European Quarterly, 4 (1974), 408-409; Parming,
} 
umbmäärast välisjõudude ässitust. ${ }^{39} \mathrm{E}$. Laaman ei näinud vabadussõjalastel välismaiseid eeskujusid ${ }^{40}$ ja neid ei nimetanud ka Johan Holberg. Tema järgi olid vabadussõjalased "ajanud sügavale oma juured ja võitnud pinda surmava propagandaga Riigikogu ja seal istuvate parteide vastu”. ${ }^{41} \mathrm{O}$. Mänd süüdistas vabadussõjalaste propagandat Eesti destabiliseerimises, kuna "juba ka teised erakonnad poolsõjaväelisi löögiüksusi organiseerivad”. ${ }^{42}$ M. Raud mainis vabadussõjalaste piiramatut võimuihalust, päev-päevalt suurenevaid ähvardusi, nn füüreriprintsiipi ja liikmete imbumist jõustruktuuridesse. ${ }^{43}$ Oma teises teoses nimetas Raud vabadussõjalaste eeskujuna Soome Lapuat ja väitis vabadussõjalastel olevat sidemeid kommunistidega. ${ }^{44}$

Vastukaaluks väitis J. Remmelgas, et vabadussõjalus oli inspireeritud Eesti sisepoliitilisest olukorrast, ning seletas liikumise vormiriietust ja distsipliini endiste sõjameeste suure osakaaluga. ${ }^{45}$ Sellega kattus suures osas ka W. Tominga seisukoht. Ta loetles vabadussõjalaste vigadena paraadide pidamist, mundrikandmist ja nn käetõstmisi, mis võimaldas neid süüdistada sidemetes natsidega, samuti loobumist Laidoneri toetamisest riigivanema kandidaadina. Vabadussõjalased ei olnud Tominga sõnul paremad ega halvemad teistest erakondadest. ${ }^{46}$ I. Lipping nimetas vabadussõjalaste juhiprintsiipi ja demagoogiat. 1930. aastate alguses olevat räägitud küll vabadussõjalaste kontaktidest natsionaalsotsialistidega, kuid andmed nende rahastamisest välismaalt puuduvat. ${ }^{47}$

Kõige põhjalikuma hinnangu esitas R. Marandi. Ta nimetas vabadussõjalasi "ekstra- ja antiparlamentaarseks vooluks", mis kasvas suureks vaid majanduskriisi ja "ühe positiivse eesmärgi” tõttu. Vabadussõjalaste

The collapse of liberal democracy and the rise of authoritarianism in Estonia, 40, 46; Maandi, "Rahvaesindustest iseseisvas Eestis", 21; Raun, Estonia and the Estonians, 116.

39 Klesment, "Jooni Jüri Uluotsa poliitilisest ideoloogiast", 17; Blumfeldt, "Eesti riigi rajamine ja areng", 35; Evald Blumfeldt, "Jaan Tõnissoni elu ja tegevuse ajaline taust", Jaan Tõnisson: koguteos tema üheksakümnenda sünnipäeva tähistamiseks, toim Evald Blumfeldt (Stockholm: Vaba Eesti, 1960), 16.

40 Laaman, Konstantin Päts, poliitika- ja riigimees, 243.

${ }^{41}$ Eesti põllumeeste poliitika, 90-91.

42 Oskar Mänd, "Pingerikas ajajärk Eesti sisepoliitilises elus", Jaan Tõnisson: koguteos tema üheksakümnenda sünnipäeva tähistamiseks, toim Evald Blumfeldt (Stockholm: Vaba Eesti, 1960), 227.

43 Raud, Kaks suurt, 189-19o.

44 Raud, Riigiehitaja Konstantin Päts, 103-104, 119-121.

45 Jüri Remmelgas, "Meie vaimsuse kujunemisest”, Verbum habet Sakala: Korp! Sakala 1909-1959, toim Juhan Kohjus, Heinold Okas, Paul Saar (New York: Korp! Sakala Koondis Ühendriikides, 1959), 31.

46 Tomingas, Vaikiv ajastu Eestis, 41, 44, 77, 432.

47 Lipping, "Emergence of Estonian authoritarianism", 212-213. 
ideoloogia kohta märkis Marandi, et fašismi miinimumtunnustele see ei vastanud. Sarnasuseks Euroopa analoogsete liikumistega oli militariseeritus, vormid, paraadid, "käetõstmine" ja vastuolev suhtumine, kuigi asjad, mille vastu oldi, erinesid riigiti. Välismaalt raha saamises süüdistasid vabadussõjalasi Eesti sotsialistid, aga ilmselt ei vastanud süüdistused tõele. ${ }^{48}$

12. MÄRTSI 1934 RIIGIPÖÖRE - MIKS JA KUIDAS? Et vabadussõjalased kavandasid riigipööret, väitsid $\mathrm{H}$. Moora ning $\mathrm{A}$. ja L. Annist, kes vihjasid ka pöörde õnnestumise korral Nõukogude Liidust lähtunud ohule. Päts tegutses uue, 1933. aasta põhiseaduse alusel ja tema tegevuse kiitis esialgu heaks riigikogu ${ }^{49}$ Samal seisukohal oli vabadussõjalaste riigipöördekatse osas ka R. Penno. ${ }^{50}$

E. Laaman seletas, et vabadussõjalased hakkasid valijaid terroriseerima, riigiaparaati laostama ning valmistasid ette riigipööret. Päts võttis võimu tänu 1933. aasta põhiseadusele ja riigikogu kiitis Pätsi sammud heaks. ${ }^{51}$ M. Raua andmetel pidi vabadussõjalaste riigipööre algama 12. märtsi öösel ja nende järgnenud tasalülitamisega leppis esialgu ka riigikogu. Pätsi tegevuse seaduslikkuse küsimust Raud ei tõstatanud, kuigi raamatust võis välja lugeda, et Pätsi tegevuse aluseks oli uus põhiseadus. ${ }^{52} \mathrm{Ka}$ Eesti põllumeeste liikumise ajaloos väideti, et Päts kuulutas "peale vabadussõjalaste ebaõnnestunud riigipöördekatset” 12. märtsil välja kaitseseisukorra. Riigikogu olevat kiitnud heaks mitte ainult kaitseseisukorra kehtestamise, vaid ka erakondade tegevuse peatamise ja "uue riigialuse väljatöötamise ning ellurakendamise". ${ }^{53}$

Osa autoreid väitis, et vabadussõjalased valmistusid kasutama vägivalda siis, kui nad poleks saanud võimule valimiste teel. A. Mägi esitas oma käsitlustes mõneti vastukäivaid seisukohti. Ta kirjutas, et 1933. aasta põhiseadusest lähtuv ulatuslik riigipea võim oli põhjuseks, miks erakonnad soovisid vältida vabadussõjalaste kandidaadi valimist riigipeaks ja toetasid valimiste edasilükkamist. Kuid ka Mägi arvates olid vabadussõjalased valmis võtma võimu jõuga, kui see poleks õnnestunud valimistel. Riigikogu

48 Marandi, "Riigivõimude tasakaalu otsingul", 65; Marandi, Must-valge lipu all, $I$, 476-498.

49 Ojamaa, Varmas, Varmas, Eesti ajalugu, 359-36o.

50 Penno, "Eesti vabadusvõitluse traditsioon ja Eesti Rahvusnõukogu", 13.

51 Laaman, Konstantin Päts, poliitika- ja riigimees, 248-253.

52 Raud, Kaks suurt, 190-192; Raud, Riigiehitaja Konstantin Päts, 120, 122.

53 Eesti põllumeeste poliitika, 302. 
kiitis heaks nii 12. märtsi kui valimiste edasilükkamise. ${ }^{54}$ Vabadussõjalastest lähtuva hädaohu osas olid samal seisukohal ka G. von Rauch ja raamatu "Eesti ajalugu noorsoole" autorid. ${ }^{55} \mathrm{E}$. Blumfeldti käsitluses oli vabadussõjalaste eesmärgiks "haarata võim riigis endi kätte" ja riigikogu kiitis Pätsi sammud vabadussõjalaste poliitilisest elust väljalülitamisel heaks. ${ }^{56}$

T. Parmingu sõnul oleks võinud puhkeda kodusõda, kui vabadussõjalased poleks olnud 1934. aasta valimistel edukad. Parming meenutas ka Pätsi ja Laidoneri soovi saada vabadussõjalaste riigivanema kandidaadiks. ${ }^{57}$ T. Raun väitis, et kuigi hilisemal uurimisel ei leitud selle kohta tõendeid, hoiti Pätsi ja tema toetajate väitel ära kodusõda. Rauna arvates ei tohiks vabadussõjalaste ja Pätsi vastuolusid ületähtsustada, kuna Päts soovis saada nende presidendikandidaadiks. ${ }^{58}$

Mitu autorit jäi umbmääraseks. J. Sikkar rääkis üldsõnaliselt vabadussõjalastest lähtuvast ohust. ${ }^{59} \mathrm{~V}$ riigikogu saadik $\mathrm{H}$. Maandi viitas nende "vastutustundetult tekitatud korralagedusele" ja seletas motiive, miks riigikogu alguses Pätsi toetas - saadikud uskusid, et oht riigi julgeoleku vastu pidi olema tõsine, muidu ei oleks riigi juhtkond selliseid samme astunud. Ka Maandi väitis, et Päts kuulutas 12. märtsil välja kaitseseisukorra uue põhiseaduse alusel. ${ }^{60} \mathrm{O}$. Pukk kirjutas, et "vabadussõjalaste liikumine oli võtnud sellise ulatuse ja saavutanud sellise mõju, et üleminek juhiprintsiibil juhitavale riigikorrale oleks ilma radikaalsete vastuabinõudeta osutunud paratamatuks". ${ }^{61} \mathrm{Ka}$ A. Rei teosest ei selgu, mida halba vabadussõjalased täpselt kavandasid. ${ }^{62} \mathrm{R}$. Taagepera viitas oma artiklis samuti "kodukootud fašistidest” lähtuvale ohule ning 1933. aasta põhiseadusele, mis oli seaduslikuks aluseks 12. märtsil toimunule. ${ }^{63} \mathrm{E}$. Uustalu näitas oma ingliskeelses teoses 12. märtsi riigipööret kui valitsuse aktsiooni lõpetamaks avalikku

\footnotetext{
54 Artur Mägi, “1937. aasta põhiseadus”, Akadeemia, 11 (1990), 2380; Mägi, Kuidas valitseti Eestis, 88-89; Artur Mägi, Das Staatsleben Estlands während seiner Selbständigkeit, 1: das Regierungssystem (Stockholm: Almquist \& Wiksell, 1967), 279.

55 Rauch, The Baltic States, 150; Parijõgi, Algma, Koit, Eesti ajalugu noorsoole, 298.

56 Blumfeldt, "Eesti riigi rajamine ja areng", 37.

57 Parming, The collapse of liberal democracy and the rise of authoritarianism in Estonia, 44-46.

58 Raun, Estonia and the Estonians, 119.

59 Sikkar, "Pagulaskonna ideoloogiline hoiak", 8-9.

60 Maandi, "Eesti iseseisvusaegsest parlamentarismist", Hoiak: koguteos, toim Artur Grönberg, Aleksander Kaelas, Aksel Mark (Stockholm: Eesti Teataja, 1946), 44-45; Maandi, "Rahvaesindustest iseseisvas Eestis", 23.

61 Otto Pukk, "Jüri Uluots riigimehena", 22.

62 Rei, The drama of the Baltic peoples, 165.

63 Taagepera, "Civic culture and authoritarianism in the Baltic States, 1930-1940", 408-409.
} 
korda ohustav agitatsioon. Uue põhiseaduse kohaselt olid ellu viidud meetmed üpriski (quite) seaduslikud. ${ }^{64}$

Vabadussõjalaste tegevust enne 12. märtsi ei kritiseerinud R. Taagepera ja R. Misiunas, kes siiski väitsid, et Päts kasutas võimu haaramiseks uut põhiseadust ${ }^{65} \mathrm{E}$. Blumfeldt seletas oma teises käsitluses 12. märtsi mõneti vastuoluliselt: Päts kehtestas kaitseseisukorra, haarates "samade vahendite järele" (mida kasutas J. Tõnisson valitsusjuhina 1933. aasta suvel) ja tuginedes "vahepeal jõustunud uuele põhiseadusele". Riigikogu algul toetas valitsust, kuid siis saadeti laiali. ${ }^{66} \mathrm{~A}$. Mägi teise teose kohaselt olid kõik erakonnad veendunud, et eelseisvail valimistel toetab nende valijaskond vabadussõjalasi, nad nõudsid Pätsilt viimaste pidurdamist ja pärast 12. märtsi kiitsid vabadussõjalaste poliitilisest elust väljalülitamise heaks. Erakonnad võtsid "kergendustundega" vastu ka muud piirangud, näiteks valimiste edasilükkamise ning koosolekute ja meeleavalduste keelamise. ${ }^{67}$ Oma eestikeelses teoses ei selgitanud E. Uustalu Pätsi motiive 12. märtsi riigipöördeks, esitades vaid väite "haigest rahvast". Nii eesti- kui ingliskeelses teoses tunnistas Uustalu vabadussõjalaste häid tulemusi kohalikel valimistel jaanuaris 1934, eestikeelses ka nende kandidaadi kindral Andres Larka häid võimalusi võita riigivanema valimised. ${ }^{68}$

Kriitilisemad autorid väitsid, et Pätsi tegevuse põhjuseks 12. märtsil oli hirm jääda valimistel võimust ilma. J. Remmelgas juhtis tähelepanu, et 1935. aasta kohtuprotsessil ei esitatud ühtegi süütõendit vabadussõjalaste riigipöördekavatsuse kohta. ${ }^{69}$ Samal seisukohal oli W. Tomingas. Ta esitas detailse kirjelduse 12. märtsi sündmuste käigust, riigi juhtkonna põhjendustest ja refereeris ajakirjanduse seisukohti. Tomingas eitas, et vabadussõjalased soovisid tulla võimule jõuga. Sa muti viitas ta Pätsi kõrgele enesehinnangule ja teadlikkusele oma teenetest riigi ees, mistôttu pidas viimane ennast ainuvõimalikuks kandidaadiks riigijuhi kohale. ${ }^{70}$

Ka H.-J. Uibopuu väitel võis Pätsi motiveerida kartus, et ta ei osutu valituks riigivanemaks. Parlament küll kinnitas kaitseseisukorra, aga mitte valimiste edasilükkamise. ${ }^{71}$ I. Lipping nimetas 12. märtsi pöörde põhjustena

64 Uustalu, The history of Estonian people, 205.

65 Misiunas, Taagepera, The Baltic States, 11-12.

66 Blumfeldt, "Jaan Tõnissoni elu ja tegevuse ajaline taust", 16.

67 Artur Mägi, "Rahvahääletus ja rahvaalgatus Eestis”, Omariikluse taustal: üliópilasselts Raimla koguteos, toim Arnold Kivimäe jt (Uppsala: Üliõpilasselts Raimla Kirjastus, 1955), 40.

68 Eesti Vabariik 1918-1940, 138.

69 Remmelgas, "Meie vaimsuse kujunemisest", 34-35.

70 Vt peatükk "12. märts" raamatus Tomingas, Vaikiv ajastu Eestis, 93-121.

71 Uibopuu, "The constitutional development of the Estonian Republic", 19. 
Pätsi ja Laidoneri isiklikke ambitsioone. Kuna vabadussõjalased ei osutanud Pätsi riigipöördele mingit vastupanu, ei olnud nad järelikult valmistunud vägivallaga võimu haarama. Kuigi Pätsi riigipöörde kiitis heaks parlament, juhtus see enne, kui autoritaarse süsteemi tõeline loomus avaldus. ${ }^{72}$

R. Marandi seletusel muutusid vabadussõjalased 1933. aasta rahvahääletuse järel nii "ühiskonnaelu ohustavaks rühmituseks", et Päts soovis nad "otsustavalt Eesti poliitilisest elust välja lülitada". Kuid 12. märtsil läks Päts kaugemale - kaitseseisukorda ja enda tõlgendusel ka uut põhiseadust kasutades surus ta maha kodanike põhiõigused. Oma peateoses nimetas Marandi 12. märtsi põhjusena kombinatsiooni Pätsi ja Laidoneri murest vabadussõjalaste kihutustöö pärast ning isiklikest võimuambitsioonidest. Oli täiesti selge, et mingit putši vabadussõjalased 12. märtsil ei plaaninud ning Päts ja Laidoner teadsid seda. ${ }^{73}$

Ümberkorraldused 1934.-37. Aastal. H. Moora ning A. ja L. Annisti Eesti ajalugu ei eitanud demokraatia lämmatamist 12. märtsile järgnevatel aastatel. "Vaikival ajastul" valitses Päts omaenda vastutusel, erakonnad saadeti laiali, ajakirjandus võeti kontrolli alla ja loodi riiklik propagandatalitus. Raamatus mainiti ka rahvuskogu referendumit, mida rahvas toetas, ning valitsuse kandidaatide võiduga lõppenud rahvuskogu valimisi, kus opositsiooni tegevust takistati. ${ }^{74} \mathrm{~J}$. Klesment märkis, et autoritaarkorda hinnati valesti kui diktatuuri, kuigi tegelikult tehti kõike demokraatia päästmiseks ja "otstarbekalt" parandamiseks. Samas väitis O. Pukk, et opositsiooni tekkimine Pätsile 12. märtsi riigipöördele järgneval perioodil oli põhjustatud poliitilisest konkurentsist ja 1934. aasta aprillis toimuma pidanud valimiste edasilükkamine oli põhiseadusega kooskõlas. ${ }^{75}$

M. Raud süüdistas vastasseisus Pätsi ja opositsiooni vahel just viimaseid, kelle tegevuse ajendiks olnud "tülitsemise ja intriigitsemise" võimaluste kadumine. Pätsi aga kujutas autor kui rahva isa ja kasvatajat, ületades tema idealiseerimisel igasugused piirid. Demokraatlike vabaduste kõige olulisema piiranguna mainis Raud korduvalt erakondade tegevuse seismapanekut ja vaid üksikuil juhtudel ka sõnavabaduse puudumist. Opositsiooni tegevusele seatud piiranguid seoses 1938. aasta põhiseaduse koostamisega

72 Lipping, "Emergence of Estonian authoritarianism", 209, 213-214.

73 Marandi, "Riigivõimude tasakaalu otsingul", 66; Vt alapeatükk "Kaheteistkümnes märts" teoses Marandi, Must-valge lipu all, I, 419-476.

74 Ojamaa, Varmas, Varmas, Eesti ajalugu, 360-361.

75 Klesment, "Jooni Jüri Uluotsa poliitilisest ideoloogiast", 17; Pukk, "Jüri Uluots riigimehena”, 25. 
ta ei maininud. ${ }^{76}$ Eesti põllumeeste liikumise ajaloos on vastav peatükk, ilma sellele viitamata ja tugevalt kärbituna, maha kirjutatud Raua raamatust "Kaks suurt". Põhiõiguste piirangutest mainiti üksnes erakondade tegevuse keeldu. ${ }^{77}$

E. Blumfeldt, G. von Rauch, A. Rei, R. Taagepera ja R. Misiunas ning Tõnissoni mälestusraamatu autorid jäid oma hinnangutes eelpool kirjeldatute vahepeale, mainides ühte või teist piirangut, kuid võtmata nende kohta selget seisukohta. ${ }^{78}$ "Eesti ajalugu noorsoole" märkis, et riigikogu ei kutsutud enam kokku, kuid ei korraldatud ka valimisi, kuna Päts "leidis, et rahva meeleolud pole veel küllalt rahunenud, arvestas võimalust, et ta enam Riigikogu enamuse poolehoidu ei leia, ja ei algatanud enam omalt poolt Riigikogu kokkukutsumist". ${ }^{79}$

T. Parmingu nägemuses oli 1934. aasta suveks vabadussõjalastest lähtuv oht likvideeritud ja poliitiline stabiilsus saavutatud, kuid Päts ei piirdunud sellega. Kuigi Päts kritiseeris 1933. aasta põhiseadust kui diktaatorlikku valitsemist võimaldavat, kasutas ta ise seda samal otstarbel. ${ }^{80} \mathrm{H}$. Maandi kirjeldas riigikogu erakorralist istungjärku sügisel 1934, mainides muuhulgas, et pärast koosoleku ootamatut lõppu kasutati saadikute hoonest lahkumise kindlustamiseks sõjaväge. ${ }^{81}$

Teised autorid ütlesid otse välja, et Päts rikkus aastatel 1934-37 seadusi. J. Sikkar seletas, et Päts ja tema ringkond ületasid võidujoovastusest või autoritaarsete ideede mõjul oma võimupiire ja kaldusid demokraatiast kõrvale. Kuna aga eesti rahvas on oma põhiolemuselt demokraatlik, siis tekkis sellise valitsemisviisi vastu opositsioon ja valitsus oli sunnitud otsima teid tagasipöördumiseks demokraatia radadele. ${ }^{82}$

E. Laaman kirjeldas Pätsi tegevust detailselt, opositsiooni tekkimist aga seletas poliitilise konkurentsiga. Et 1938. aasta põhiseaduse koostamine ja kehtestamine rahvuskogu kaudu oli kehtiva põhiseaduse vastane ja ebademokraatlik, selgub ka Laamani tekstist, kuid seda põhjendas viimane

\footnotetext{
76 Raud, Kaks suurt, 192-198, 208-211; Raud, Riigiehitaja Konstantin Päts, 123-125.

77 Eesti põllumeeste poliitika, 302-305.

78 Blumfeldt, "Eesti riigi rajamine ja areng", 37-38; Rauch, The Baltic States, 154-159; Rei, The drama of the Baltic peoples, 165; Misiunas, Taagepera, The Baltic States, 11-12; Maria Kleitsman, "Võitlus jätkub", Jaan Tõnisson: koguteos tema üheksakümnenda sünnipäeva tähistamiseks, toim Evald Blumfeldt (Stockholm: Vaba Eesti, 1960), 254-258; Mikk Põlde, "“Postimehe" areng ja sekvestri alla võtmine", ibid., 284-285.

79 Parijõgi, Algma, Koit, Eesti ajalugu noorsoole, 299.

80 Parming, The collapse of liberal democracy and the rise of authoritarianism in Estonia, 56-59.

81 Maandi, "Rahvaesindustest iseseisvas Eestis", 24-25.

82 Sikkar, "Pagulaskonna ideoloogiline hoiak", 9.
} 
otstarbekusega.$^{83} \mathrm{Ka}$ A. Mägi süüdistas “vaikiva ajastu” probleemides just erakondi, mis oma huvides enam Pätsi ei toetanud. Mägi ütles välja, et valimiste edasilükkamine märtsis 1934 ja rahvuskogu rahvahääletus olid põhiseadusevastased, kuid õigustas mõlemat hädaolukorraga. 1938. aasta põhiseadus nõudis jõustumiseks referendumit, kuid Päts jättis selle ära kartusest, et valmis põhiseadus oleks seal pakutava valitsemisviisi tõttu võinud mitte pälvida rahva heakskiitu. ${ }^{84}$

E. Uustalu ingliskeelne käsitlus 1934.-37. aasta kohta oli tasakaalukas, ei süüdistanud otseselt kumbagi poolt ega põhjendanud Pätsi tegevust otstarbekusega, kuigi nimetas Pätsi valitsust autoritaarseks. Eestikeelses käsitluses väitis Uustalu, et Pätsi valitsemine dekreetidega oli 1933. aasta põhiseaduse alusel küll võimalik, kuid osade seaduste, sh riigieelarve kehtestamine dekreedi korras ka vaieldav. Autori sõnul oli "vaikiv ajastu" vähemalt alguses puhtakujuline diktatuur. Kõik erakonnad olid selle kehtestamises ühel meelel, eriarvamused tekkisid demokraatiale tagasipöördumise kiiruse küsimuses. ${ }^{85}$

H.-J. Uibopuu sõnul valitses Päts pärast riigikogu 1934. aasta kevadistungjärgu lõpetamist üksnes dekreetide abil, mis ilmselt väljus põhiseaduses seatud piiridest. Pätsil ei olnud õigust rahvuskogu kokkukutsumise küsimust 1936. aastal rahvahääletusele panna, kuid rahva heakskiit võis Pätsi ebaseadusliku teo seadustada. Kuigi 1933. aasta põhiseadus nõudis põhiseaduse muutmise heakskiitmist referendumil, võis rahvas selle õiguse delegeerida rahvuskogule. ${ }^{86}$

W. Tominga hinnang Pätsi tegevusele alates 12. märtsist oli äärmiselt kriitiline. Ta pidas Pätsi valitsust ebaseaduslikuks alates aprillist 1934, kui jäeti ära riigivanema ja parlamendi valimised. ${ }^{87} \mathrm{~T}$. Rauna järgi teostas Päts sisuliselt riigipöörde ja rikkus põhiseadust, kuna lükkas edasi 1934. aasta valimised. Järgnevaid demokraatia piiranguid kirjeldas Raun adekvaatselt. ${ }^{88}$ R. Marandi piirdus 12. märtsi järel kujunenud valitsemissüsteemi kirjeldamisel peamiselt sündmustega kuni 1936. aastani. Ta nentis, et Pätsi riigipöördega sisse seatud autoritaarrežiim jäi põhiliselt kehtima kuni 1940.

83 Laaman, Konstantin Päts, poliitika- ja riigimees, 254, 271-272, 302-304.

84 Mägi, Kuidas valitseti Eestis, 91, 94-95; Mägi, "Rahvahääletus ja rahvaalgatus Eestis", 41-42; Mägi, "1937. aasta põhiseadus", 2394.

85 Uustalu, The history of Estonian People, 205-206; Eesti Vabariik 1918-1940, 139, 143-144.

86 Uibopuu, "The constitutional development of the Estonian Republic", 19-22.

87 Vt peatükk "Riigipöörde tulemused" ja järgmised peatükid raamatus Tomingas, Vaikiv ajastu Eestis, 122 jj.

88 Raun, Estonia and the Estonians, 119-121. 
aastani ja jätkus õiguskorra murenemine, mida tähendas ka 1938. aasta põhiseaduse koostamine ja kehtestamine..$^{89}$

AASTAD 1938-40 - KAS SUUND DEMOKRAATIA TAASTAMISE POOLE? Seda, et 1938.-40. aastaks oli demokraatia taastatud, väitsid vaid üksikud autorid. A. Rei järgi taastas 1. jaanuaril 1938 jõustunud uus põhiseadus parlamentaarse demokraatia uuel ja tasakaalustatumal kujul. Päts lahendas Rei sõnul põhiseadusliku kriisi Eestis ilma suuremate raskusteta, kasutades poolautoritaarset süsteemi, mis seati sisse seaduslikult, ilma vägivaldse riigipöördeta ja (1936. aasta) rahvahääletuse teel. ${ }^{90} \mathrm{Ka} \mathrm{M}$. Raud väitis, et 1938. aasta põhiseaduse kehtima hakkamisega oli demokraatia taastatud, kuid arvustajatele oli Päts endiselt diktaator, nüüd juba inertsist. Sellele vasturääkivalt kirjutas Raud oma raamatus hiljem, et opositsiooni nõuet kodanikuvabaduste taastamise kohta ei saanud täita ka veel sügisel 1939. ${ }^{91}$

Teise osa autorite arvates võeti 1938. aastast alates suund demokraatia taastamisele. H. Moora ning A. ja L. Annist märkisid, et 1938. aasta põhiseadus oli kompromiss autoritaarsete ja demokraatlik-parlamentaarsete printsiipide vahel, ülekaaluga esimestel. Võimud talusid aastatel 1938-40 pisikese opositsiooni olemasolu parlamendis ja olude rahunedes oleks Eesti riigikord arenenud jälle demokraatia suunas. ${ }^{92}$

J. Klesmenti arvates ei saanud poliitilisi parteisid pärast 1938. aasta põhiseaduse kehtima hakkamist "mitmeil põhjustel” ellu kutsuda. Samas väitis O. Pukk, et naasmist "normaalsesse olukorda" takistasid alguses "sisepoliitilised olukorrad" ja siis rahvusvahelised sündmused. ${ }^{93}$ Teisal kirjutas Klesment: "Ajaloo sündmused ei võimaldanud Vabariigi Presidendile K. Pätsile üleminekuaega tema viimases faasis normaalsetes oludes lõpetada, nagu see oli ta vankumatu soov." 94 J. Sikkar seletas, et kuigi 1938. aasta riigivolikogu valimistel ei olnud parteid peale Isamaaliidu lubatud, oli elu "rahva survel" arenemas demokraatlikus suunas ja VI riigikogu tulnuks vaadata kui üleminekuparlamenti. ${ }^{95}$

89 Rein Marandi, Must-valge lipu all: vabadussõjalaste liikumine Eestis 1929-1937, II; illegaalne vabadussõjalus (1934-1937) (Stockholm: Department of Baltic Studies at the Stockholm University, 1997), 17-25, 206.

90 Rei, The drama of the Baltic peoples, 165.

91 Raud, Riigiehitaja Konstantin Päts, 129, 154.

92 Ojamaa, Varmas, Varmas, Eesti ajalugu, 361-363.

93 Klesment, "Jooni Jüri Uluotsa poliitilisest ideoloogiast", 17; Pukk, "Jüri Uluots riigimehena", 27.

94 Johannes Klesment, "Riiklik tegevus ei tohi katkeda", Eesti Rahvusnõukogu toimetised, 1 (1948), 10.

95 Sikkar, "Pagulaskonna ideoloogiline hoiak", 9. 
E. Uustalu kritiseeris nii inglis- kui eestikeelses raamatus riigivolikogu ebaausaid valimisi 1938. aastal. Eestikeelse raamatu kokkuvõttes kiitis autor riigi juhtkonda, kuna vaatamata $\mathrm{V}$ riigikogu enamuse poolt tehtud "ilmsetele vigadele" õnnestus põhiseaduse kriis ületada vajaduseta seada sisse sõjaväeline diktatuur. Demokraatliku riigikorra taastamine oli Eestis käimas, kuid selle lõpetas Nõukogude okupatsioon. ${ }^{96}$ Viimast seisukohta toetasid ka "Eesti ajalugu noorsoole", G. von Rauch ja E. Blumfeldt. ${ }^{97}$

EÜS-i 12. albumis kirjutas Aleksander Warma: "Teame, et poliitilise korra kujundumine Eestis a. 1939 arenes demokraatlikus suunas, kuid me ei saa väita, et autoritaarsed sugemed, mis iseloomustavad "vaikivat ajastut", oleksid siis juba kadunud olnud." ${ }^{88}$ Raamatus "Kaks suurt" kirjeldas M. Raud VI riigikogu tegevuse algust kui poliitilise kursi muutust, samas ilmselgelt tegelikkust ilustades. Erakondade ja ajakirjandusvabaduse puudumist Raud siiski ei varjanud, erakondi endiselt Pätsi suu läbi kritiseerides. Opositsiooni nõudmist taastada kodanike põhiõigused ei olnud Raua sõnul võimalik täita veel ka 1939. aastal, nüüd juba välispoliitilistel põhjustel. ${ }^{99}$

R. Taagepera oli arvamusel, et 1938. aastal algas demokraatia taastamine Eestis, mille katkestasid Teine maailmasõda ja Nõukogude okupatsioon. ${ }^{100}$ Mõni aasta hiljem toimunud loengul väitis Taagepera aga, et "Leedus kadus demokraatia 1926, Eestis ja Lätis 1934. Parlamentaarse demokraatia juurde naasis Eesti 1938, teised üldse mitte". ${ }^{101}$

Mitu autorit ei väitnud midagi demokraatia taastamisega alustamise kohta aastatel 1938-40. E. Laaman põhjendas üheparteivalimisi VI riigikogusse "otstarbekusega", väites samas, et Päts ei olnud muutunud vaba poliitilise organiseerumise vastaseks. ${ }^{102} \mathrm{H}$. Maandi oli seisukohal, et VI riigikogu polnud tegelik rahvaesindus, vaid "surrogaat", ning ei märkinud demokraatia peatse taastamise võimalust. ${ }^{103}$ 1938. aasta riigivolikogu valimisi nimetas ebademokraatlikuks ka A. Mägi, väites, et nende tulemused ei peegeldanud valijaskonna tõelist tahet. 1938. aastal tekkinud valitsemissüsteemis domineerisid valitsus ja president. Mägi sõnul hakkas 1939. aastal

96 Uustalu, The history of Estonian people, 207-208; Eesti Vabariik 1918-1940, 141-144, 149.

97 Parijõgi, Algma, Koit, Eesti ajalugu noorsoole, 307-308; Rauch, The Baltic States, 159; Blumfeldt, "Eesti riigi rajamine ja areng", 38-39.

98 Aleksander Warma, "Eesti välispoliitikast 1939", Eesti Üliõpilaste Seltsi album, XII (1955), 81.

99 Raud, Kaks suurt, 215-216, 218-219, 224.

100 Taagepera, "Civic culture and authoritarianism in the Baltic States, 1930-1940", 411.

101 "Leedu, Läti ja Eesti 1940-1980", Vaba Eestlane, 4. oktoober 1983, 2.

102 Laaman, Konstantin Päts, poliitika- ja riigimees, 310-311.

103 Maandi, "Eesti iseseisvusaegsest parlamentarismist", 45-46; Maandi, "Rahvaesindustest iseseisvas Eestis", 26-28. 
olukord muutuma, kui mitmed saadikud soovisid, et riigikogu asuks oma põhiseaduslikule positsioonile ja valitsus loobuks seaduste andmisest presidendi dekreetidena. Valitsus aktsepteeris seda soovi. ${ }^{104}$

Ka Eesti põllumeeste liikumise ajaloos ei arutatud demokraatia taastamise perspektiive. Kuid märgiti, et 1938. aasta riigivolikogu valimised olid vabad ning saabunud oli "kindel kord", "avar areng ja õnn". 105

R. Marandi nentis, et veel 1940. aasta juuniks ei olnud jõutud kodanike põhiõiguste taastamise ega demokraatlikult valitud rahvaesinduseni ning Pätsi tegevuses oli olulisel kohal soov säilitada poliitiline võim Isamaaliidu käes. ${ }^{106} \mathrm{Ka}$ W. Tomingas nõustus, et 1940. aasta suveks ei olnud alanud tagasipöördumine demokraatliku riigivalitsemise juurde. ${ }^{107} \mathrm{H}$.-J. Uibopuu liigitas Eesti 1934. aastal põhiseaduse alusel loodud kvaasi-diktatuuriks, mis hiljem osutus ainsaks riigiks, kus õnnestus luua süsteem, millesse oli kaasatud ka parlament (mille valimise aususes autor kahtles). Demokraatia taastamise kohta ei öelnud Uibopuu midagi. ${ }^{108} \mathrm{Ka}$ R. Taagepera ja R. Misiunase raamatus, erinevalt Taagepera varasemast artiklist, ei mainitud demokraatia taastamise seisu ega perspektiivi. ${ }^{109}$

Mitu nooremat läänes hariduse saanud teadlast demokraatia taastamise perspektiivi ei uskunud. I. Lipping nentis, et Pätsi poolt loodud valitsemissüsteem oli tavapärane autoritaarne režiim, üsna mõõdukas kõiges peale poliitika. Mõni aasta pärast selle loomist hakati tegema esimesi samme demokratiseerumise suunas, kuid uus põhiseadus andis presidendile nii palju võimu seadusandlikus valdkonnas, et demokraatia taastamine oli ebatõenäoline. ${ }^{110}$ T. Parmingu järgi ei muutnud uue põhiseaduse kehtima hakkamine ja 1938. aasta valimised märkimisväärselt autoritaarset korda, küll aga seadustasid selle. Teisal ütles Parming selgelt välja, et Eesti ei olnud 1930. aastatel demokraatlik riik: erakonnad ja poliitilised koosolekud (peale valitsuse korraldatute) olid keelatud, kehtis tsensuur ning tegutsesid ainupartei ja propagandatalitus. "Keegi ei uskunud seda [et Eesti oli

104 Mägi, "Kuidas valitseti Eestis”, 101; Mägi, “1937. aasta põhiseadus”, 2397-2398.

105 Eesti põllumeeste poliitika: ülevaade Eesti põllumeeste liikumisest 1917-1955, 304-305.

106 Rein Marandi, “Endiste riigivanemate märgukiri”, Jaan Tõnisson: koguteos tema üheksakümnenda sünnipäeva tähistamiseks, toim Evald Blumfeldt (Stockholm: Vaba Eesti, 1960), 288.

107 Tomingas, Vaikiv ajastu Eestis, 432-434.

108 Uibopuu, "The constitutional development of the Estonian Republic", 25, 27.

109 Misiunas, Taagepera, The Baltic States.

110 Lipping, "Emergence of Estonian authoritarianism", 213. 
1930. aastatel demokraatlik riik] tollal Läänes ja seda ei usuta praegugi, kui pagalused välja arvata."111

R. Marandi arvates ei taastatud Eestis demokraatiat ka 1938. aasta põhiseadusega, kuigi mõned nii väidavad. Marandi nimetas 1938. aastal dekreedi korras antud trükiseadust, koosolekute seadust ja kaitseseisukorra seadust "permanentseks tõkkeks" demokraatliku riigikorra taastamise teel. ${ }^{112} \mathrm{~T}$. Raun viitas Parmingu ja Lippingu viimati nimetatud hinnangutele, kuid tema enda arvamus jäi segaseks. ${ }^{113}$

\section{Analüüs ja kokkuvõte}

Paguluses kujunes 1930. aastate Eesti ajaloole kaks lähenemist. Kõigepealt arvukam ja pagulaskonnas kaugelt enam levinud, kuid vähese allikakriitikaga ja tänaste teadmiste kohaselt ebaobjektiivne Pätsi ülistav lähenemine, mille moodustasid populaarteaduslikes teostes, varasemates Eesti ajaloo üldkäsitlustes ja meedias ilmunud seisukohad. Seda nn võitjate ajalugu jutustasid peamiselt autorid, kellel oli 1930. aastate Eestiga, mitmel ka Pätsi võimuaparaadiga otsene isiklik side. Valdavalt alates 1970. aastatest konkureerisid nendega nooremad, läänes hariduse saanud professionaalsed uurijad. Nad ei soovinud "vabadusvõitluse huvides" kirjutada ebaobjektiivseid käsitlusi ning avaldasid oma teadustöö tulemusi pigem võõrkeeltes ja teadusväljaannetes, mille mõju pagulaskonna hulgas jäi tagasihoidlikuks.

Käesoleva artikli teises peatükis refereeritud käsitluste põhjal on võimalik luua üldistus 1930. aastate Eesti sisepoliitika kohta esitatud seisukohtadest. Selle kohaselt oli 1920. aasta põhiseadus liiga parlamendikeskne ja seda tulnuks muuta (muutmise eestkõnelejaks oli K. Päts), kuid erakonnad ei suutnud leida selles küsimuses ühist keelt. Majandus- ja poliitilise kriisi tulemusena rahvas enam riigi juhtkonda ei usaldanud, mis võimaldas vabadussõjalastel saavutada agressiivse propaganda toel suure populaarsuse. Autorite hinnang vabadussõjalastele oli valdavalt negatiivne, lahknedes peamiselt selles, milliste riikide äärmuslastest vabadussõjalased autorite arvates eeskuju võtsid ning milliseid negatiivseid jooni nende poliitilises tegevuses veel leiti.

1934. aasta 12. märtsi riigipöördest ei vaadanud mööda ükski teos. Valdavalt leiti, et vabadussõjalased olid oma karistuse igal juhul ära teeninud:

111 Parming, The collapse of liberal democracy and the rise of authoritarianism in Estonia, 59-64; Tõnu Parming, "Vabariigi juhtkond riigikriisi vahendajana", Metroo teine raamat, toim Enno Klaar jt (Stockholm, 1979), 102.

112 Marandi, "Riigivõimude tasakaalu otsingul”, 79.

113 Raun, Estonia and the Estonians, 122-123. 
ühtede arvates kavandasid nad kindlasti riigipööret, teiste arvates aga üksnes ebaedu korral valimistel ning kolmandate sõnul olid vabadussõjalased lihtsalt ohuks riigikorra stabiilsusele. Mingeid tõendeid vabadussõjalaste ebaseaduslike kavatsuste kohta ühelgi autoril ei olnud ja vaid üksikud mainisid, et neid ei esitatud ka järgnenud kohtuprotsessil. Näiteks E. Laaman põhjendas leebeid karistusi 1935. aasta protsessil kohtu armulikkusega, kes lootis, et vabadussõjalased end parandavad. ${ }^{114}$ Pätsile soodsa narratiivi toetamiseks esitati otseseid valesid just paguluse kõige tuntumates teostes. Laaman väitis, et vabadussõjalaste kokkulepe kindral Laidoneriga esitada viimane 1934. aasta kevadel riigivanema kandidaadiks jäi katki Laidoneri põhimõtete pärast, mitte vabadussõjalaste otsuse tõttu eelistada kindral Larkat. Vabadussõjalaste samasisulistest konsultatsioonidest Pätsiga vaikis autor täielikult. ${ }^{115} \mathrm{Ka} \mathrm{M}$. Raua väitel keeldus just Laidoner vabadussõjalaste riigivanema kandidaadiks saamast. Raud esitas ka valeväite, nagu oleks Larka kogunud presidendikandidaadina Pätsist ja Laidonerist vähem toetusallkirju ja seega polnud tal lootustki valituks saada. Veel valetas Raud 1938. aasta riigivolikogu valimiste kohta, väites, et valimiskampaanias opositsioonile takistusi ei tehtud. ${ }^{116}$ Pätsi enda poliitilisi ambitsioone ja kartust kaotada aprillis 1934 toimuma pidanud valimistel vabadussõjalastele nimetasid vähesed.

Valdava enamuse autorite arvates seadustas Pätsi tegevuse 12. märtsil 1934 eelmisel aastal rahva heakskiidu saanud üliautoritaarne põhiseadus. See väide ei ole korrektne. ${ }^{117}$ Samuti väitis mitu autorit, et lisaks kaitseseisukorra kehtestamisele oli Pätsil parlamendi heakskiit ka teistele demokraatiat kitsendavatele sammudele, kuigi valimisi edasi lükkava dekreedi andis Päts mitu päeva hiljem ja oma kõnes riigikogule 15. märtsil 1934 ta seda ei maininud. Samuti ei kritiseerinud Päts selles kõnes kordagi 1933. aasta põhiseadust. ${ }^{118}$ Autorid kirjeldasid kodanikuõiguste kitsendusi ja muid

114 Laaman, Konstantin Päts, poliitika- ja riigimees, 262.

115 Ibid., 243-245.

116 Raud, Kaks suurt, 189-190, 216; Raud, Riigiehitaja Konstantin Päts, 119.

117 Vt Peeter Kenkmann, "Kas 1933. aasta põhiseadus lubas autoritaarset valitsemist?", Tuna, 3 (2009), 42-49.

118 15. märtsi kõnes rääkis Päts vabadussõjalaste valmisolekust võtta vajadusel võim jõuga ning rahva haigusest, kes ei olevat võimeline oma kohust täitma. Päts ei öelnud sõnagi teiste poliitiliste organisatsioonide, peale vabadussõjalaste, kavatsetavast tasalülitamisest, valimiste edasilükkamisest või teistest kogu kodanikkonda puudutavatest piirangutest. Vt Riigikogu V koosseis: täielikud protokollid ja stenograafilised aruanded: III ja IV istungjärk: 65. koosolekust 27./28. juunil 1933-122. koosolekuni 16. märtsil 1934 (Tallinn: 1934), 1435-1438. Saadikud ei esitanud Pätsile ühtegi küsimust ega võtnud sõna ka järgmisel päeval, kui üleriigilise kaitseseisukorra kehtestamine heaks kiideti. 
"vaikiva ajastu" negatiivseid tendentse erineva detailsusega ning andsid neile erinevaid hinnanguid. Opositsiooni seisukohtade toetajad hindasid Pätsi järgnevaid samme liigsetena. Pätsi toetajad kritiseerisid kogu tollast erakondlikku süsteemi, seletasid opositsiooni tegevust poliitilise konkurentsiga ja Pätsi tegevust otstarbekusega, ning rõhutasid vajadust riigielu põhjalikult reformida, sh uuesti muuta alles hiljuti ka Pätsi poolt avalikult toetatud 1933. aasta põhiseadust.

1938. aasta põhiseaduse koostamist kirjeldati paguluses kaheti. Ühtede autorite jaoks oli tegemist põhiseaduse rikkumisega, mida ei eitanud ka Pätsi positiivselt suhtuvad autorid, näiteks Laaman. Teised seda küsimust ei tõstatanudki. Peaaegu keegi ei salanud opositsiooni diskrimineerimist rahvuskogu rahvahääletusel, rahvuskogu valimistel ja riigivolikogu valimistel. Kuid nii kehtiva põhiseaduse rikkumist uue põhiseaduse koostamisel kui ka kodanikuõiguste piiramist põhjendati otstarbekusega või Pätsi tahtega, mida nenditi kui fakti, sellele hinnangut andmata.

Paljude autorite jaoks algas 1938. aastal demokraatia järk-järguline taastamine, kuigi näiteid konkreetsetest sammudest nad enamasti ei toonud. Seega jääb ebaselgeks, millisena oleksid need autorid näinud riigikorda selles Eestis, kus nende väitel oleks demokraatia taastamine olnud lóppenud. Teise maailmasõja ja Nõukogude okupatsiooni algus toodi põhjuseks, miks "demokraatlik protsess" katkes. Vaid vähesed autorid keeldusid uskumast, et Päts soovinuks lähitulevikus demokraatia taastada ja kellegagi võimu jagada.

Kuigi detailides, nagu riikidest erinevate kombinatsioonide moodustamine, kelle paremäärmuslastest vabadussõjalased autorite arvates oma ideoloogias ja tegevuses eeskuju võtsid või mida Eesti riiki destabiliseerivat nad kevadel 1934 kavandasid, võisid autorite hinnangud lahkneda, siis üldine suundumus oli enamusel käsitlustest sarnane. See narratiiv ei süüdistanud demokraatia kadumises riigipöörde korraldanud Pätsi ja riigi juhtkonda, kes olid võimul 12. märtsist kuni Nõukogude okupatsioonini 1940. aasta suvel. 1930. aastate poliitilise kriisi peasüüdlasteks said kuni 1934. aastani tegutsenud erakonnad ja eriti vabadussõjalased, kellele omistati natsionaalsotsialismi- või fašismimeelsust ja võimuhaaramise kavatsust, ning 1920. ja 1933. aasta põhiseadused. Selline ajalookäsitlus sobis ka Teise maailmasõja võitnud demokraatlikele lääneriikidele apelleeriva vabadusvõitluse huvidega, kuna kirjeldas demokraatia võitu väidetavalt Itaaliast ja Saksamaalt inspiratsiooni ammutanud paremäärmuslaste üle.

Tagantjärele tarkusega võib öelda, et suurem osa paguluses ja eriti selle esimestel kümnenditel nn võitjate ajaloo kirjutajate poolt antud hinnanguid 
on edaspidi ja eriti pärast Eesti iseseisvuse taastamist ümber lükatud. Vabadussõjalastele kleebiti äärmuslaste silt külge liiga kergekäeliselt ja põhjendusi esitamata, kuid tänapäeva arusaamade kohaselt nad selleks ei kvalifitseeru. ${ }^{119}$ Vabadussõjalaste riigipöörde kavatsust 1934. aastal ei ole ükski ajaloolane tõestanud ka pärast seda, kui taas tekkis juurdepääs Eesti arhiivides säilitatavatele dokumentidele, ning 12. märtsile järgnevaid sündmusi ei hinnata enam Pätsi riigimehetarkuse eduloona. ${ }^{120}$

Samuti ei olnud tõsiseltvõetav pagulaspoliitikute väide, et 1930. aastate Eesti sisepoliitika objektiivne kajastamine võinuks kahjustada Eesti iseseisvuse taastamise eest peetava võitluse huve. Esiteks olid Eesti riigiasutuste arhiivid jäänud kodumaale ja neid oli Nõukogude asutustel alati võimalik kasutada propagandategevuses eelmise võimu diskrediteerimiseks. Nii väitis näiteks R. Marandi 1975. aastal. ${ }^{121}$ Teiseks kajastasid 1930. aastatel Eestis resideerunud välisriikide diplomaadid siin toimunut oma valitsustele enamasti objektiivselt ja nimetasid sündmusi nende õigete nimedega. Kuigi Päts sooritas riigipöörde demokraatia kaitsmise loosungi all, ei olnud välisriikidel tegelikult erilisi illusioone pöörde põhjendatuse ja demokraatia peatse taastamise osas. Mis aga ei tähendanud, et lääneriigid poleks eelistanud Pätsi autoritaarset valitsust teistele võimalikele valitsejatele. ${ }^{122}$ Ei ole teada, et Eestis kuni 1940. aastani kehtinud ebademokraatlik riigikord oleks hiljem hakanud takistama iseseisvuse taastamise eest peetavat võitlust.

\footnotetext{
119 Kasekamp, The radical right in interwar Estonia, 3, 159; Marandi, Must-valge lipu all, $I, 483-487$.

120 Vt nt Jaak Valge, "Konstantin Päts, 12. märts ja Moskva”, Tuna, 2 (2007), 42-66; Jaak Valge, "Eesti vabadussõjalased ja Saksa natsionaalsotsialistid: ideoloogia, poliitiline taktika ja kontaktid", Tuna, 3 (2009), 50-62; Peeter Kenkmann, "1937. aasta põhiseadus - autoritaarse režiimi "reformimise" katse", Tuna, 1 (2013), 70-89; Peeter Kenkmann, “"Universaalne valitsemisvahend": kaitseseisukord Eesti Vabariigis aastatel 1938-1940", Tuna, 1 (2018), 20-38; Pajur, Konstantin Päts: poliitiline biograafia, II, 800-802.

121 “Teretulnud teos", Teataja, 20. detsember 1975, 6.

122 Nõukogude Liidu juhtkonnas hinnati Pätsi riigipööret positiivselt: Ilmjärv, Hääletu alistumine, 154-158. J. Valge on uurinud välisriikide suhtumist 12. märtsi riigipöördesse ning tema väitel hakkas riigi juhtkond vabadussõjalasi välisdiplomaatide ees diskrediteerima 1934. aasta alguses, kui ebaõnnestusid läbirääkimised Pätsi või Laidoneri esitamiseks riigivanema kandidaadiks vabadussõjalaste poolt. Pätsi riigipööre ei leidnud kolme riigi valitsustes erilist hukkamõistu: Jaak Valge, "London, Berliin ja Moskva ning Eesti 1934. aasta riigipööre”, Tuna, 1 (2012), 38-61. Heino Arumäe väitel kiitis ka Soome juhtkond selle heaks: Heino Arumäe, Eesti ja Soome: sõjast sõjani (Tallinn: Argo, 2018), 347.
} 


\section{AвSTRACT: On the writing in exile of the history of the Republic of Estonia in the 1930 s}

The 1930 s were pivotal in Estonia. The faith that Estonians placed in parliamentary democracy diminished under the influence of the worldwide economic crisis (also known as the Great Depression). In a referendum held in October of 1933, draft legislation for amending the constitution won strong popular support. This amendment had been introduced by the right-wing radical League of Veterans movement, which had recently become politically active. It would have required a head of state with extensive power to be elected in April of 1934. This election was not held because Konstantin Päts, the Premier at that time, executed a coup on 12 March 1934 with the assistance of the country's law enforcement agencies. Päts justified his actions by referring to an alleged threat posed by the League of Veterans. He suspended most civic rights and ruled the country in an authoritarian manner until the start of the Soviet occupation in 1940.

This article analyses the description of these events in the works written by authors of Estonian origin that were published in exile in the years of Soviet occupation (until 1991). Viewpoints concerning five problems are of interest here: how the situation in Estonia at the start of the 1930s was described, what was the assessment of the actions of the League of Veterans, how what took place on 12 March 1934 was explained, how the subsequent years of the undemocratic regime were described, and whether a course was set aimed at restoring democracy again in Estonia at the end of the 1930 .

After the restoration of Estonia's independence, researchers of Estonian history have mentioned only a few works written in exile on the 1930s, mostly by professional historians. Actually, more written studies on Estonia in the 1930s, which were at different academic levels, were published in exile. In addition to historians, the authors of these works were also journalists, politicians and others. Many of them had been in the service of the Päts government in the past and thus were partial. The aim of the article is to develop a narrative of Estonia in the 1930s that takes into consideration the viewpoints of as many treatments published in exile as possible, and to compare this narrative to the current state of research on this theme.

Researchers of Estonian history faced several challenges in exile. Since the most important task of the expatriate community was considered to be the fight for the restoration of Estonia's independence, the interests of this objective also had to be taken into consideration in writing history. Many believed that this meant keeping quiet about the undemocratic government 
of the latter half of the 1930s. Public opinion in exile raised independent Estonia's most important statesmen, who were repressed by the Soviet regime, to the status of martyrs, thus making it more difficult to criticise their actions. Those who disagreed with these views, including professional historians of the younger generation who mostly received their education in the West, were accused in the expatriate press of betraying the interests of the fight for freedom, of not being rigorous in their academic research, and of unfamiliarity with conditions in the Estonian homeland. This last argument was important since most written historical sources were in Soviet Estonia and were thus inaccessible to researchers living in exile.

Our analysis shows that in the judgement of almost all of the works consulted, Estonia's constitution of 1920 was too parliament-oriented and an expectation for amending the constitution emerged in society at the start of the 1930s. Since the political parties did not reach a consensus regarding this issue, the League of Veterans gained a great deal of popularity with its draft legislation for constitutional amendment. The attitude of the overwhelming majority of authors towards the League of Veterans was negative, accusing them of copying the examples of foreign right-wing parties and of employing excessively aggressive propaganda methods. In the opinion of the overwhelming majority of authors, the League of Veterans had only themselves to blame for the banning of their movement - they either planned to overthrow the government in the spring of 1934 or were simply a threat to public order. The authors related reservedly to Konstantin Päts, who governed the country in an authoritarian manner after the coup of 12 March 1934. Although many of the steps that Päts took until 1940 were questionable in legal terms, and some overtly violated the constitution, several studies pointed to expediency as justification for his actions. The opinions of the authors diverged in their assessments of whether or not we can speak of the beginning of the restoration of democracy after the drafting of the new constitution and the holding of parliamentary elections in 1938. Many older works argue that this was exactly the case, adding that the Soviet occupation interrupted this process. Later works from the $1970 \mathrm{~s}$ and 1980 os tend not to agree with this assessment.

In summary, two approaches to the history of Estonia in the 1930 s took shape in exile. First an approach that favoured Konstantin Päts and the authoritarian regime that was in effect in 1934-40. The viewpoints of this approach prevailed in most popular academic works aimed at a broad readership, and in earlier general treatments of Estonian history, but also in the expatriate media. Mostly starting from the 1970s, younger professional 
researchers competed with this so-called mainstream. They were more critical of the authoritarian government of the country in the latter half of the 1930s. Yet they published the results of their research mostly in foreign languages and in academic publications, and their effect on the majority of the expatriate community was modest.

Most of the judgements provided by the so-called mainstream authors in exile, especially during the first decades of exile, have been refuted after the restoration of Estonia's independence. This applies particularly to judgements regarding the League of Veterans, who were portrayed in exile as the main culprits of the political crisis that broke out at the start of the 1930 s and in the abandonment of democracy. Expatriate authors too easily accused the League of Veterans of National Socialism or fascism because according to current assessments, the League did not correspond to those attributes. Not one researcher has hitherto been able to find evidence of plans on the part of the League of Veterans to overthrow the government, to which Päts appealed when he himself seized power in 1934. The opinion that steps started being taken in 1938 for restoring democracy in Estonia, which the Soviet occupation cut short, is also not borne out. There is similarly no basis for the argument expounded at that time by ideologists of expatriate politics that the way the history of the Republic of Estonia was depicted in exile could affect the outcome of the struggle that was being waged to restore Estonia's independence.

KeYwords: Estonia, the 1930s, War of Independence veterans, Konstantin Päts, historical writing, exile

Peeter Kenkmann (b. 1977) is a PhD student at the University of Tartu.*

* Correspondence: Institute of History and Archaeology at University of Tartu, Jakobi 2, Tartu 51005, Estonia. E-mail: peeterkenkmann@gmail.com 